\title{
Valuing Ecosystem Services for Sustainable Landscape Planning in Alpine Regions
}

Author(s): Adrienne Grêt-Regamey, Ariane Walz, and Peter Bebi

Source: Mountain Research and Development, 28(2):156-165.

Published By: International Mountain Society

DOI: http://dx.doi.org/10.1659/mrd.0951

URL: http://www.bioone.org/doi/full/10.1659/mrd.0951

BioOne (www.bioone.org) is a nonprofit, online aggregation of core research in the biological, ecological, and environmental sciences. BioOne provides a sustainable online platform for over 170 journals and books published by nonprofit societies, associations, museums, institutions, and presses.

Your use of this PDF, the BioOne Web site, and all posted and associated content indicates your acceptance of BioOne's Terms of Use, available at www.bioone.org/page/terms_of_use.

Usage of BioOne content is strictly limited to personal, educational, and non-commercial use. Commercial inquiries or rights and permissions requests should be directed to the individual publisher as copyright holder. 
Alpine regions provide diverse ecosystem goods and services (ES) to human society. Yet as many of these ES are not bought or sold, their value must be estimated using a surrogate for observable behavior witnessed in the marketplace. The present article reviews ES valuation studies conducted in the European Alps. In addition, we present the results of a case study where we integrated the value of selected ES (avalanche protection, scenic beauty values, $C$-sequestration, habitats of capercaillie [Tetrao urogallus]) into the planning of new settlement areas in the tourism resort of Davos (Swiss Alps). Benefit estimates derived from the economic valuation studies tend to be specific to a particular method, ecosystem, and socioeconomic circumstance. The case study shows, however, that consideration of ES values can help identify the most beneficial locations for new development if appropriate selection of ES is made, and if these ES can be valued in a spatially explicit form. The achievements of research to date indicate that accounting for the value of multiple ES in an Alpine region will increasingly make important information available to planners.

Keywords: Economic valuation; ecosystem services; landscape planning; Alpine region; GIS; Switzerland.

Peer-reviewed: March 2008 Accepted: April 2008

\section{Introduction}

A critical part of landscape planning is assessing the impacts of alternative plans. Assessment of this sort has many dimensions that are important in formulating optimal development strategies. In view of tightening budgets, economic concerns often become the most important point for landscape planners. Yet the value of resources produced by the natural environment-the value of ecosystem goods and services (ES) - is often not included into the planning process, as most of the environmental benefits are not marketed and therefore do not command a market price. The Alps in particular provide major ES such as protection against natural hazards (floods, avalanches, and landslides), carbon sequestration and storage in biomass and soil (see the Kyoto Protocol), natural resources (eg fodder plants, timber as renewable raw material for energy production and construction), tourism and recreation (skiing, hiking, biking, bird watching, and hunting), freshwater, and biodiversity. Hence changes in ES may negatively affect the economy.

The need for ES values was already noted by Westman in 1977. Since then the valuation of ES has become one of the most significant and most rapidly evolving research areas in environmental and ecological economics (eg Costanza et al 1997; Daily 1997; Heal 2000). Above all, estimation of ES values on a global scale has engaged both scientists and policymakers. Costanza et al (1997), for example, valued the world's ES in the range of USD 16-54 trillion per year. But regional studies that value multiple ecosystem functions simultaneously and capture the "before and after" states during environmental change are rare (Bockstael et al 1995; Mallawaarachchi et al 1996; Higgins et al 1997). On a local scale, however, these "before and after" types of analysis are important aids for rational decision-making where the conservation of ecosystems may be pitted against development.

Landscape planning needs to be supported by accurate and detailed information about the spatial distribution of ES and their value. Geographic Information Systems (GIS) have been known for decades as useful tools to model spatial data. They are particularly useful in Alpine regions, where complex topography and distinct environmental gradients require a special consideration of spatial patterns. Several authors have linked ES quantification processes to economic valuation methods in a GIS (Eade and Moran 1996; Mallawaarachchi et al 1996; Termansen et al 2004; Grêt-Regamey et al 2007a). Yet mapping of ES for planning purposes has only recently become a focus of research, especially in conservation planning (Chan et al 2006; Naidoo and Ricketts 2006).

The present paper aims to provide landscape planners with information on the current state of research on ES valuation for the European Alps and to show the potential of ES valuation for sustainable landscape planning in Alpine regions. To accomplish this, we first provide a review of $\mathrm{ES}$ valuation studies conducted in the European Alps. We then present the results of a case study investigating the value of ES for sustainable landscape planning in an Alpine region-the Landscape Davos (Grisons, Switzerland). The main objectives of the case study are to (1) present a framework facilitating the integration of ES into landscape planning, and (2) show the benefits of considering ES in landscape planning.

In the case study, we consider $4 \mathrm{ES}$ that are relevant for identifying optimal settlement development areas in Alpine regions, namely avalanche protection, scenic beauty, C-sequestration, and habitat. The study was embedded in the ALPSCAPE project of the Swiss National Research Program 48 (NRP48), addressing sustainable use of Swiss mountain areas (Bebi et al 2005). Finally, we discuss possible future directions for ES valuation in the Alps with respect to the achievements of research to date and insights gained in the course of research for the case study. 


\section{Economic valuation of Alpine ecosystem services}

ES valuation studies conducted in the European Alps are scattered throughout the scientific literature. Table 1 synthesizes major studies identified in a literature review, which involved a review of databases on the World Wide Web and a recent bibliography of stated preference studies in Austria, Germany and Switzerland (Elsasser and Meyerhoff 2007; Meyerhoff and Elsasser 2007). Studies not conducted in Alpine areas were excluded from the list. If more than one publication was related to a study, only one of these publications was included in the list, normally the one that includes the most comprehensive description of methods and results. To ensure comparability of all values, the results of each study were converted from their original currency to their equivalent in 2007 euros using the EU Harmonised Index of Consumer Prices (Office for National Statistics 2008).

Among the studies assessed, 12 assign economic values to non-market goods and services produced by Alpine regions. The majority of the ES valuation studies used the contingent valuation method-a stated preference (SP) method. Revealed preference (RP) methods construct the demand curves for these goods and services by observing consumer behavior. As stated preference methods are based on hypothetical scenarios, they allow for a considerably wider range of situations. The disadvantage of stated reference methods, however, is that also the stated transactions are only hypothetical and may not reveal how people might behave in a functioning market.

The review demonstrates considerable variability among the euro values derived from the different studies that deal with similar ES. For example, for scenic beauty, Baumgart (2005) and Grêt-Regamey et al (2007b) both investigated the preferences for development of an urban area using photo manipulation. Respondents in both studies expressed negative preferences for such a change, but willingness to pay varied between $406 €$ /year (Baumgart 2005) and $832 €$ /year (Grêt-Regamey et al 2007b), respectively. The preference pattern was confirmed in Tangerini and Soguel (2004), who used a revealed preference method. In contrast, preferences for changes in forest cover varied more profoundly: while Baumgart (2005) found that people were willing to pay a tax of $12 €$ /year to support forest expansion, Grêt-Regamey et al (2007b) did not find any statistical differences in the responses. Data on ES values in the Alps are too sparse, however, to determine whether these differences could be explained by different preferences among people or whether they are due to the methods and the data underlying these methods. Yet one should recognize that most of the valuation estimates presented here are highly site-specific.
Furthermore, most of the studies focus on valuing one single ES at one discrete location. For example, the value of biodiversity is investigated by Jäggin (1999) in the Swiss Jura and Getzner (2000) in the Hohe Tauern National Park in Austria, while the value of recreation is estimated by Glück and Kuen (1977) in the Ahornboden (Austria), by Hackl and Pruckner (1997) in the Kalkalpen National Park (Austria), and by Gios et al (2006) in the Campogrosso (Italy). Yet each Alpine area provides more than one ES. Goio et al (2005) simultaneously valued recreational, aesthetic, ecological and protective functions of forests located in the Province of Trento (northeast Italy) in order to integrate the values into an accounting system. Grêt-Regamey et al (2007a) valued selected ES provided by the Landschaft Davos in Switzerland using GIS. These two studies faced the challenge of comparing values estimated using different methods. But both recognized that their output was not an aggregate indicator representing the total economic value of the study area. Goio et al (2005) stressed that estimations in their study were very approximate values, but were still useful in giving some idea of the degree of the benefits produced by forests. Grêt-Regamey et al (2007a) emphasized that the aim of such integrative approaches is not to put an accurate absolute "price tag" on the environment; rather, they are intended to help decision-makers balance the impacts of different planning options on the economic accounting of a region, and guide them in selecting sustainable and economically feasible development strategies. Several aggregate indicators of ES have been suggested to date (eg Heal and Kriström 1998; Vincent 2000; Boyd and Banzhaf 2007). However, their implementation presents unique challenges and considerations, including how to address varying perceptions of the societal importance of different services, and how to communicate information about these services to both decision-makers and the general public.

Little is known about the most appropriate way to transfer value estimates for ES across spatial scales. Several authors have transferred the unit of ES values estimated by Costanza et al (1997) on a global scale to their study region (Sutton and Costanza 2002; Williams et al 2003). Yet, on a local scale, regional studies are more important aids by far for rational decision-making. The international, peer-reviewed literature in the field of environmental benefit transfer has grown substantially and transfer methods are increasingly being recognized as distinct from those used in original nonmarket valuation studies (Wilson and Hoehn 2006). GIS has been suggested as a suitable tool to transfer the results of meta-analysis of ES values to other regions. In combination with Bayesian approaches, this would make it possible to quantify the uncertainties of such exercises (Bergland 2006). 
TABLE 1 Overview of studies valuing ecosystem services in the Alps; WTP = willingness to pay; SP = stated preference; RP = revealed preference.

\begin{tabular}{|c|c|c|c|}
\hline Study & Ecosystem service (ES) & Method & Location \\
\hline $\begin{array}{l}\text { Baumgart } \\
(2005)\end{array}$ & Scenic beauty & Discrete-choice experiment (SP) & Bernese Oberland (Switzerland) \\
\hline $\begin{array}{l}\text { Grêt-Regamey et } \\
\text { al (2007b) }\end{array}$ & Scenic beauty & Contingent valuation method (SP) & Davos (Switzerland) \\
\hline $\begin{array}{l}\text { Tangerini and } \\
\text { Soguel (2004) }\end{array}$ & Scenic beauty & Hedonic pricing method (RP) & Valais (Switzerland) \\
\hline Jäggin (1999) & Biodiversity & Contingent valuation method (SP) & Jura (Switzerland) \\
\hline Getzner (2000) & Biodiversity & Contingent valuation method (SP) & Hohe Tauern National Park (Austria) \\
\hline $\begin{array}{l}\text { Glück and Kuen } \\
\text { (1977) }\end{array}$ & Recreation & Travel cost method (RP) & Grosser Ahornboden (Austria) \\
\hline $\begin{array}{l}\text { Hackl and } \\
\text { Pruckner (1997) }\end{array}$ & Recreation & Contingent valuation method (SP) & Kalkalpen National Park (Austria) \\
\hline Gios et al (2006) & Recreation & Contingent valuation method (SP) & Campogrosso (Italy) \\
\hline $\begin{array}{l}\text { Löwenstein } \\
\text { (1995) }\end{array}$ & Avalanche protection & Contingent valuation method (SP) & Hinterstein/Allgäu (Germany) \\
\hline Goio et al (2005) & $\begin{array}{l}\text { Recreation, scenic beauty, } \\
\text { carbon sequestration, pro- } \\
\text { tective forest }\end{array}$ & $\begin{array}{l}\text { Market approaches, contingent } \\
\text { valuation, replacement costs }\end{array}$ & Alpine forests in Trentino (Italy) \\
\hline $\begin{array}{l}\text { Grêt-Regamey et } \\
\text { al (2007a) }\end{array}$ & $\begin{array}{l}\text { Scenic beauty, habitat, ava- } \\
\text { lanche protection, carbon } \\
\text { sequestration }\end{array}$ & $\begin{array}{l}\text { Contingent valuation method, replace- } \\
\text { ment cost, risk analysis, and market } \\
\text { approaches (SP and RP) }\end{array}$ & Davos (Switzerland) \\
\hline
\end{tabular}

\section{Case study in the Swiss Alps: Framework for integrating ecosystem service values into landscape planning}

\section{Study area: The Landschaft Davos}

Alpine regions that depend on income from tourism are especially sensitive to changes in ES. The Landschaft Davos is a mountain resort town located in the eastern part of the Swiss Alps at $1560 \mathrm{~m}$ (Figure 1). It is one of the largest municipalities of Switzerland with a total area of 25,500 ha, 13,000 permanent residents, and up to 28,000 tourists during peak season in winter. The central part of the main valley hosts the core settlement with well-established urban and tourist infrastructures. The rest of the main valley and the three side valleys have remained rural with a few small, scattered settlements, and a landscape strongly dominated by mountain agriculture. The tourism development of 


\section{Sample units}

View of planned urban expansion project compared to current view

View of planned water reservoir project compared to current view for tourists

View of planned project increasing habitat diversity for animals and plants, compared to current view

View of planned small expansion of forest compared to current view

View of planned ski slope compared to current view

View of planned large urban expansion compared to current view

View of planned large forest expansion compared to current view

View of natural landscape compared to cultural landscape

View of natural landscape compared to no view

Project to triple the area suitable for protecting species in the Jura

Ibex species protection program

Visit to national park

Fund to maintain activities allowing the establishment of national park

Fund to revive Campogrosso area

Fund to restore protective forests to reduce avalanche risks

Landscape recreation, carbon sequestration, hydro-geological protection, values/ha

Lost ES benefits through new settlement area. For details, see case study.

Davos is closely linked to the construction of health clinics in the beginning of the $20^{\text {th }}$ century. In the 1980 s, the number of annual overnight stays reached a peak of 2.6 million. Since then, this number has decreased slightly, to about 2.3 million in 2000. Despite this situation, accommodation capacity, mainly in the area of vacation rentals and second homes, has been augmented over recent decades, leading to ongoing land consumption for housing and infrastructure aver-

\section{Unit-specific benefits (in euros, for 2007)}

Annual reduction of taxes, $406 €$ per resident

Daily decrease of railway pass cost, $2.5 €$ per visitor

Annual increase of taxes, $75 €$ per resident

Annual increase of taxes, $12 €$ per resident

Weekly reduction of vacation rental cost, $12 €$ per visitor

Weekly reduction of vacation rental cost, $16 €$ per visitor

Not significant

Monthly increase in vacation rental cost, $684 €$ per tourist, $123 €$ per resident

Monthly increase in vacation rental cost, $385 €$ per tourist, $24 €$ per resident

Monthly WTP for the project, $15 €$ (inhabitant of nearby town), $26 €$ per visitor

Mean WTP to purchase a set of colored postcards, $7 €$ per visitor and visit

Mean travel costs based on randomized car counts, without accounting for travel time, $5 €$ per visitor and visit

Annual mean WTP for "Kalkalpen Nationalpark" fund ( 3 calculation methods), $10-30 €$ per resident, $8-13 €$ per visitor, 5-13 million $€ /$ year from residents and visitors

Mean price for entry card, $5 €$ per resident and visit

Annual mean WTP for fund, $48 €$ per resident

Annual mean benefits provided by the Trentino forest: landscape recreation value, 15.5 million $€$; carbon sequestration, 4.4 million $€$; hydro-geological protection, 74.8 million $€$; total value with the production value, 138.2 million $€$

Scenic beauty, $24,000 €$ per ha and year; habitat, $2 €$ per ha and year; carbon sequestration, $3100 €$ per ha and year; avalanche protection, $64,700 €$ per ha and year

\section{Material and methods}

The framework for quantifying and valuing selected ES described in this case study is integrated in the methodological framework of the ALPSCAPE project (Lundström et al 2007). Within this project, sub-models of land use allocation (regression-based approach), material and energy flows, and economic sub-models 
FIGURE 1 Map of the Municipality of Davos. The insert at the top left shows the location of Davos in Switzerland. Davos-Platz and Davos-Dorf form the "urban center," whereas the remaining area is dominated by traditional agricultural landscape, scattered settlements, and alpine terrain. The black dots represent the settlement area from the 1992/1997 Land Use Statistics. (Map courtesy of Swisstopo)

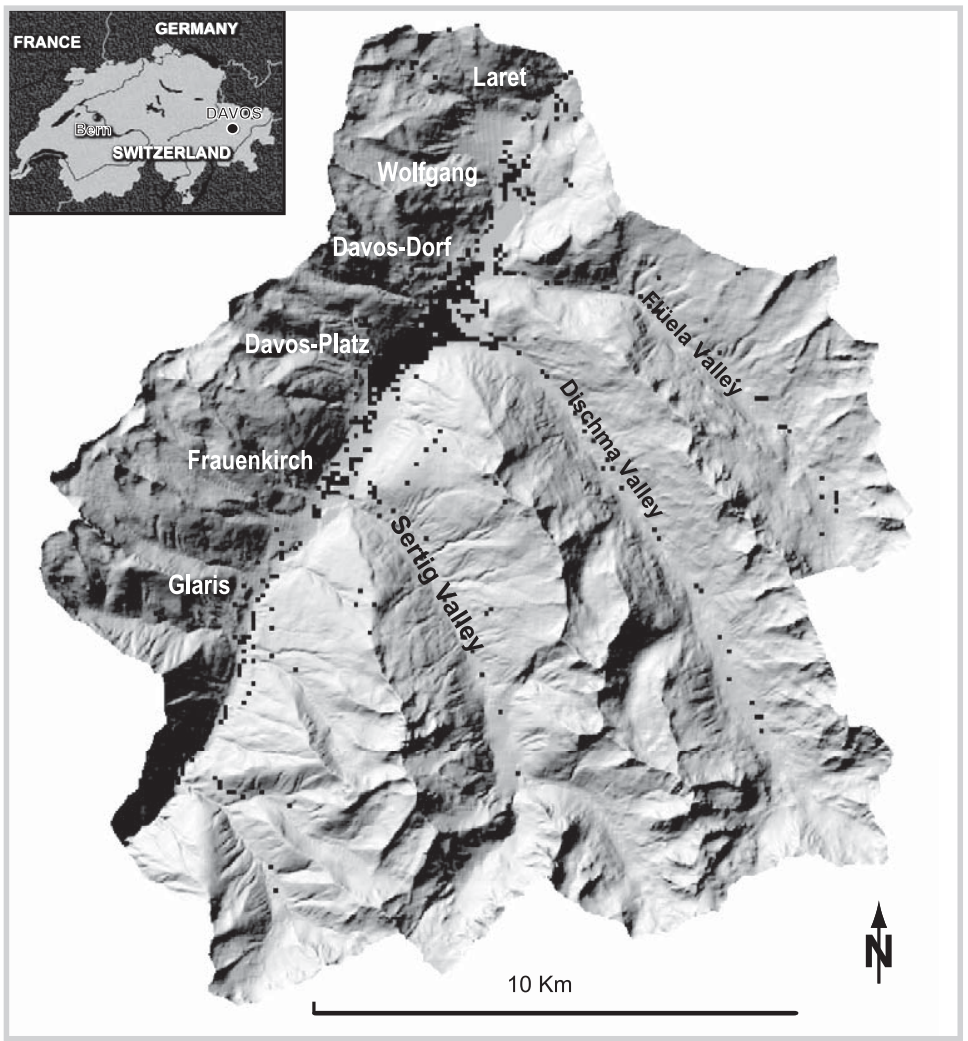

(Input-Output Analysis) are combined with assessment of selected ES to derive indicators for different scenarios in the Alpine study area. In our example, we specifically address the planning of potential locations for new accommodation capacities and aim for optimized settlement development, considering the ES as well as the economic value.

The 3 major steps relevant for understanding the case study are summarized in Figure 2. Details about these 3 procedural steps, namely specification of the land use scenario and the quantification and valuation procedures, are given in Walz (2006), Grêt-Regamey et al (2007a, 2007b), and Grêt-Regamey and Straub (2006). The selection of key ES for the case study area was conducted in collaboration with regional stakeholders (Walz et al 2007). The model is run for 12-year time intervals from the time of the last survey year for land use data to the middle of the century, namely 1997 to 2009, 2009 to 2021, 2021 to 2033, and 2033 to 2045. The 12-year time interval corresponds to the time interval between the available land use survey data (1985 and 1997) used for the land use model. Eight land use categories were differentiated, including settlement area and different categories of forest and agricultural land. Topographical variables were obtained from the 25 m digital elevation model (DEM25, Swiss Federal
Office of Topography). Results of the quantification procedure are aggregated to a hectare grid.

\section{Step 1: Land use scenario-allocation of settlement expansion}

Given its relevance to planning and the economy (Kytzia et al 2008), we focus on settlement expansion in our example. Settlement includes the area of buildings, their gardens, and other areas that visually belong to the building, as well as infrastructure. Using the land use allocation model developed by Walz (2006), we calculated probabilities of transformation into settlement area for each raster cell of the case study area, based on multiple logistic regressions. The derivation of the statistical models was based on the land use survey data from 1985 and 1997 (SFSO 2001), encompassing the Swiss mountain area. The model outputs the most likely areas of settlement expansion. Based on these most likely areas, we identified the most favorable ones for actual new development with respect to ES. In accordance with the development trends observed since the 1980 s, and neglecting the need for additional infrastructure (eg tourist infrastructure or waste water treatment), our scenario assumed that the new settlement area would be solely occupied by vacation rentals.

\section{Step 2: Spatially explicit quantification of ecosystem services}

We quantified the ES produced at each cell by using state-of-the art GIS-based models. For the quantification of avalanche protection, we used a numerical 2-D avalanche model (Gruber 1999), which calculates the avalanche runout areas. By overlaying the runout areas with a building layer, we identified the potentially endangered domiciles. For the quantification of scenic beauty, we used a 3-D GIS model of the landscape to calculate the portion of the field of view that would be occupied by a new building (Grêt-Regamey et al $2007 \mathrm{~b}$ ). In order to estimate the suitability of the cells for habitats, we used a habitat suitability model drawing on expert information from a predictive capercaillie habitat suitability model for Switzerland (Graf et al 2005). We selected capercaillie (Tetrao urogallus) as this large forest grouse has been shown to be an indicator for a rich mountain forest community (Suter et al 2002; Bollmann et al 2004). We quantified C-sequestration by estimating carbon losses in grassland, soil and biomass, as well as in forest soil and wood stock, according to the method described in the most recent Swiss Greenhouse Gas Inventory (FOEN 2006).

\section{Step 3: Valuation of ecosystem services and the new settlement area}

The data delivered by step 2 were converted into monetary units using different valuation methods in accor- 
dance with the ES valued. We valued avalanche protection by pricing damages to the vacation rentals as well as fatalities, using a risk analysis approach (GrêtRegamey and Straub 2006). Human fatalities were valued using a Life Quality Index approach amounting to CHF 5 million/fatality (Merz et al 1995). For valuation of scenic beauty, we used the results of a willingness-topay (WTP) survey conducted with tourists in the Landschaft Davos to estimate people's preferences for views (Grêt-Regamey et al 2007b). The willingness-to-pay survey states a relationship between the portion of the field of view occupied by the new vacation rentals and scenic beauty preferences. We priced habitats for capercaillie using habitat replacement costs. Several projects in Switzerland target the restoration of forest areas for capercaillie habitats to replace destroyed habitats. For C-sequestration, we used a conservative value of CHF 10 per ton of $\mathrm{CO}_{2}$ (Schmidtke and Kägi 2006).

The value of an additional hectare of vacation rentals was quantified by combining estimates of land use changes with regional Input-Output modeling for the Landschaft Davos (Kytzia et al 2008). The area requirements per overnight stay were determined based on empirical data provided by the local tourism authority for the business years 2003/2004 (Davos Tourismus, unpublished data), which amount to $9.1 \mathrm{~m}^{2} /$ bed. The economic benefits of the vacation rentals were estimated based on the consumption pattern of the tourists and the utilization ratios of the vacation rentals between the summer and winter seasons. Assuming similar consumption patterns among users and constant economic structures within the region, we estimated that an additional hectare of vacation rentals amounts to an additional CHF 150,000 per year. The impact of the change in total demand in tourism on other sectors in the region was calculated using a single Leontief multiplicator coefficient of $1.3 \%$, which corresponds to the average of the Leontief multiplicators for the different economic sectors estimated in the Input-Output Table developed for the Landschaft Davos (Grêt-Regamey and Kytzia 2007).

\section{Results}

According to our assumptions, the economic benefits of the new settlement area for vacation rentals amounted to CHF 7.7 million in the next 40 years, including the negative impacts on the selected ES. As new buildings hinder the provision of ES, the loss of ES is considerable: In 2045, the losses would amount to CHF 23 million for the 218 ha of new vacation rentals. This corresponds to $75 \%$ of the estimated benefits through increased tourism or $3.8 \%$ of the recent annual regional income (Grêt-Regamey and Kytzia 2007).

The dominant ES impacted by the new infrastructure was protection against avalanches $(60 \%$ of all considered ES values). As the buildings are mainly con-
FIGURE 2 Conceptual framework of the modeling platform to value ecosystem service (ES) losses under a settlement expansion scenario. Component 1 consists of assigning land use types and the probabilities of their changing for 12-year time steps to simulate the expansion of the settlement area. In component 2, we quantify the selected ES lost by the settlement expansion using GIS-based models; as input into the processbased model, we use the land use map showing the area of the settlement expansion and a digital elevation model. In component 3, we convert the lost ES and the benefits from settlement expansion into monetary units, using different economic valuation methods.

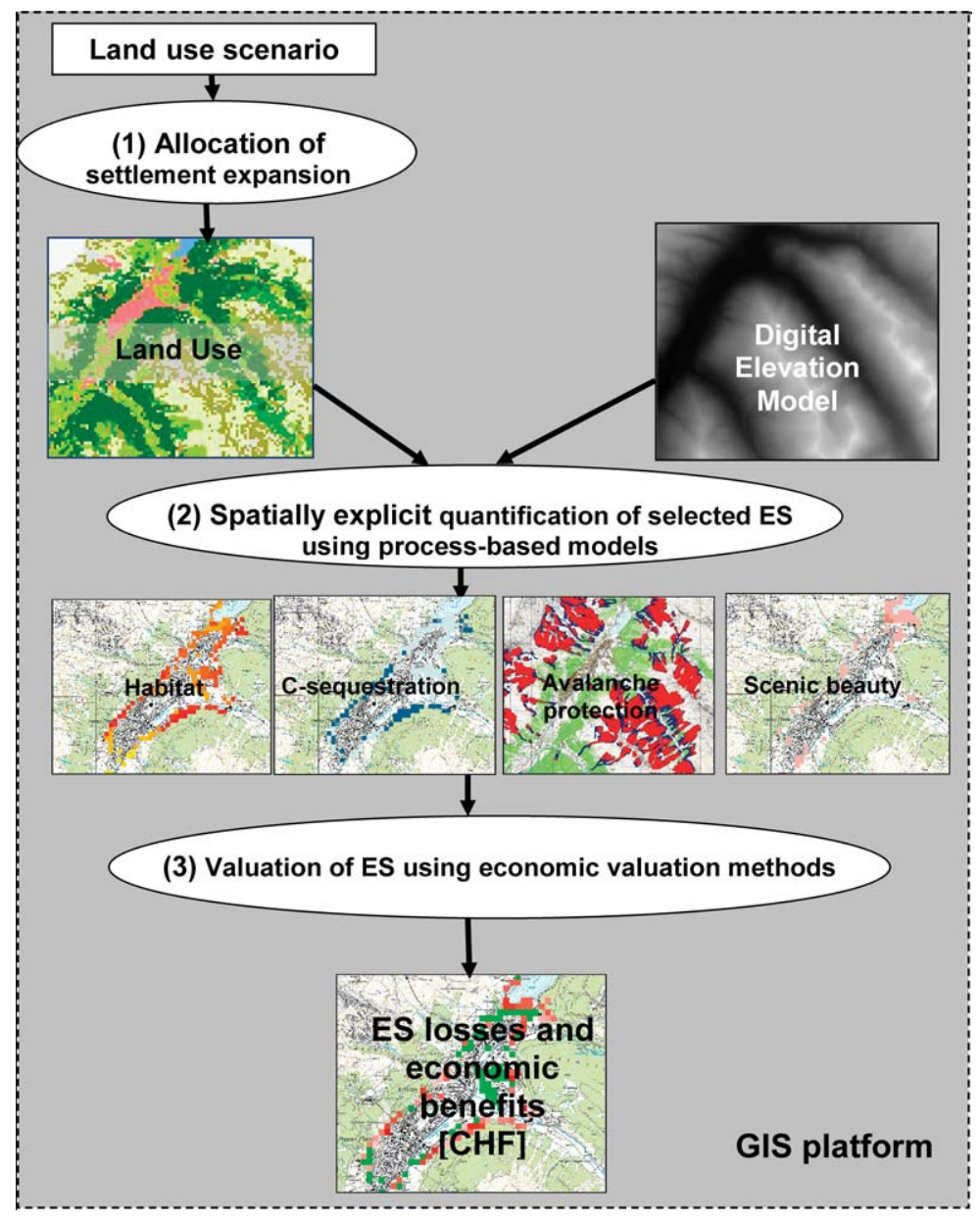

structed on agriculture and forestry parcels of which many are located in avalanche-prone areas, costs for avalanche protection might rise significantly under high development pressure. The second largest ES was scenic beauty, with $35 \%$ of the total costs for ES. Carbon sequestration and habitats for capercaillie were not greatly impacted by the new settlement areas. Together, they accounted for $5 \%$ of the total ES.

The economic benefits of the new area occupied by vacation rentals are displayed in a spatially explicit manner in Figure 3A (without including the impact of ES) and Figure 3B (with consideration of ES). The shading in Figure 3A corresponds to the probability of a change in a raster cell to a settlement area, and thus to the output of the land use model. The most probable locations for the new settlement area are located in close proximity to already existing buildings. Yet the model also predicts suitable areas situated in avalanche runout zones or along the lake. If the impacts 
FIGURES 3A AND 3B Economic benefits provided by the new settlement area occupied by vacation rentals in 2045: (A) the selected ES values are not included in the economic benefits. The dark brown values represent the most likely locations for the new settlement areas; and (B) the selected ES values are included in the economic benefits. The green values represent the best locations for new buildings, the red values the most unfavorable locations. (Map courtesy of Swisstopo)

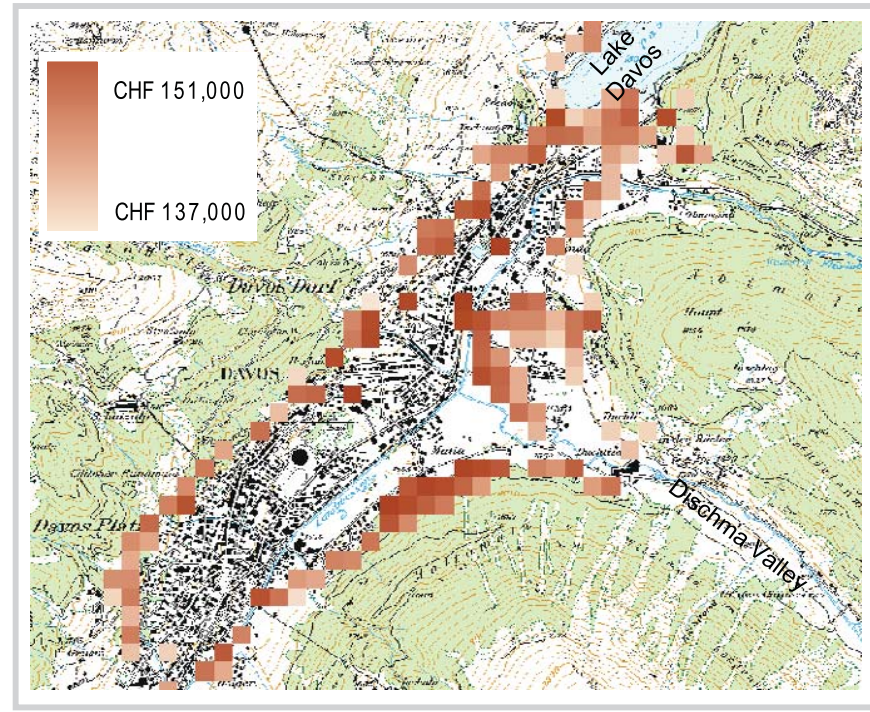

of ES are included in the economic benefits, the locations of suitable areas change drastically. If the negative impact of ES is included (Figure 3B), suitable areas for new settlement in 2045 are mainly located at the exit of the Dischma Valley. An extension of the local golf course, which is located in the residential area of Davos, was already planned in this area (Wagner 2004). Non-suitable areas are found in avalancheprone areas or around the lake, where scenic beauty is impacted.

\section{Discussion}

The literature review of ES valuation studies in Alpine regions demonstrates the challenges of estimating the economic value of ES provided by Alpine regions. Variability among the values derived from the different studies that deal with similar ES is large. One might ask whether it is really necessary to express changes in ES in monetary terms. If we assume that we (human beings, both as a society and as individuals) are forced to make choices and trade-offs about goods and services every day, we need valuation methods. Other integrative approaches such as ecological footprints (Bicknell et al 1998; Wiedmann et al 2006), life cycle assessments (Matthews and Small 2001; Suh and Huppes 2002; Suh et al 2004; Wiedmann et al 2006) or life quality indices (Nathwani et al 1997; Rackwitz 2000; Faber and Rackwitz 2004) could also help evaluate development plans with regard to environmental concerns. But as economic accounts are still proxies for the welfare components on which many political decisions are based, improvement in the accuracy of economic valuation techniques should be an aim, and methodological guidelines and standards should be developed.

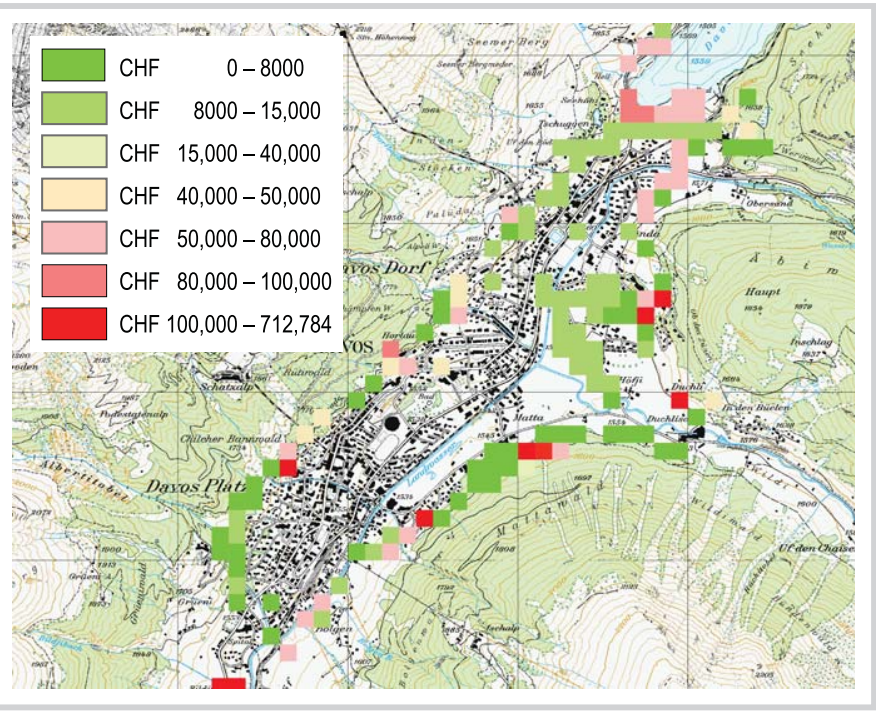

Experience from the case study in Davos underscores the usefulness of considering ES in landscape planning. We have shown that the land use model alone is not capable of predicting optimal locations with respect to $\mathrm{ES}$. But, in combination with valuation of $\mathrm{ES}$, suitable areas can be identified, large parts of which match already existing plans to expand the golf course at the exit of the Dischma Valley. A settlement expansion of 24 ha to build vacation rentals and secondary homes, which was estimated by Kytzia et al (2008) to meet peak tourism demand, could be planned in this area, and thus would have only small impacts on the ES considered in this study. Other suitable areas for settlement expansion are located near existing settlement areas, suggesting that an optimal plan would consist of denser settlement development. Yet much research remains to be done to support the integration of ES into decision-making in Alpine regions:

1. While the case study shows that the spatially explicit consideration of ES helps to determine optimal locations for landscape planning, the influence of spatial resolution on ES quantification and valuation has not yet been investigated. Especially in mountainous regions, the estimates of ES produced by a certain area might change significantly as ecosystem processes are influenced by spatial heterogeneity, and the economic significance of ES may change greatly at another scale.

2. Valuing a large selection of ES provided by a region is necessary to provide credible information to decision-makers. In our case study, however, we have only considered a few selected ES, ignoring crowding effects, noise, or other negative effects, which typically result from a denser settlement. The 
TABLE 2 Economic benefits of settlement expansion and selected ES from 1997 to 2045. Values are given in CHF. No discount rates are applied.

\begin{tabular}{|l|c|}
\hline Settlement expansion and ES & Economic benefits $\left.(\mathbf{C H F})^{\mathbf{a}}\right)$ \\
\hline Economic benefits of new vacation rentals & $31,099,879$ \\
\hline Scenic beauty & $-8,142,522$ \\
\hline Habitat & -808 \\
\hline Carbon sequestration & $-1,096,015$ \\
\hline Avalanche protection & $-14,112,408$ \\
\hline Total ES & $-23,351,753$ \\
\hline Total & $\mathbf{7 , 7 4 8 , 1 2 6}$ \\
\hline
\end{tabular}

a) Without discount rates

importance of participatory involvement in ES valuation has been shown by Wilson and Howarth (2002). Its application in selecting ES has, however, not yet been investigated, but could support the successful implementation of regional sustainable development strategies.

3. The literature review shows that results of ES valuation studies vary considerably between sites. Yet transferring the economic values captured in these studies at one place and time to another place and time is increasingly being recognized as useful given the time consumption and the financial resources for conducting such studies. Especially in connection with GIS, taking into account the fact that spatial patterns influence the variability of benefit transfer results, innovative methods are being developed (see Special Issue of Ecological Economics, Volume 60, Issue 2, 2006). The limitation of such approaches will always remain in the available spatial data and economic valuation studies, as well as the similarity between site characteristics, spatial and temporal scale, and management objectives. In this context, regional studies of spatially explicit ES values would benefit from the application of GISbased benefit transfer frameworks (Troy and Wilson 2006).

4. Uncertainties about the valuation of ES prevent them from being included in accounting frameworks (Boyd and Banzhaf 2007). Practical interest in probabilistic assessment, risk analysis, and related issues and techniques to address uncertainties has grown rapidly in recent years in the field of environmental management (WCED 1987; ADB 1990), and many different formal techniques, both numerical and symbolic, have been developed for dealing with such information (eg monotonous logic and its applications, rule-based systems, Bayes, Dempster-Shafer, fuzzy set theory). Bayesian network approaches combine many favorable proper- ties of these techniques, namely (1) supporting a structured approach to the interdisciplinary task requiring information from different specialist fields; (2) explicitly including uncertainties at all levels of the procedure; (3) identifying the major sources of uncertainty in the decision-making process; and (4) potential to improve the model dynamically with newly observed data or expert opinion. Such approaches have been applied in the field of natural hazards (Aspinall 1992; Stassopoulou et al 1998; Grêt-Regamey and Straub 2006) and benefit transfer (Atkinson et al 1992; León et al 2002; Lehr 2005; Bergland 2006). But their merits for valuing multiple ES should be explored in more detail.

5. The preference of future generations for ES might change, which would modify the results of our case study. The choice of discount rate in ES valuation has been a subject of dispute for a long time (eg Hasselmann et al 1997; Heal 2000). As we do not know enough about preferences and growth in the future, we can use different combinations of discount rates to illustrate the sensitivity of the benefits to the assumptions. If we assume a discount rate of $0 \%$ for the ES benefit losses, a view which is supported by Parfit (1993), and a constant value of $3 \%$ for the regional income to address economic growth (Nordhaus 1994), the total benefits of the settlement area in 40 years become greater than if we assume a discount rate of $3 \%$ for both ES losses and the benefits of the new settlement area. But if we assume a higher discount rate for ES losses than for the regional income provided by the new settlement area, we get a negative total economic benefit for the settlement expansion within 40 years. This shows that the valuation of ES is closely intertwined with social objectives. Should preferences for preserving ES increase in the future, the economic benefits of settlement expansion might decrease significantly. 
6. If applied for the purpose of designing land use development plans, the framework presented in the case study can be extended to provide a tool for comprehensive landscape planning. In this study, however, we have only considered settlement expansion as a development option and ignored all other possible land uses. Investigating the effect of different land use development options on the ES and on regional benefits will be an important future application of the model. While avalanche protection, habitat, scenic beauty, and carbon sequestration are only a few of the ES provided by a region, others could easily be integrated into the flexible modeling framework.

We conclude that valuation studies to date have been performed for relatively few ES at a limited number of sites in the Alps. Hence our ability to generalize from studies presented here is limited. Nevertheless, the case study shows that accounting for the value of multiple ES in an Alpine region adds a new important facet to the information available to planners. Thus, considering the many limitations of ES valuation, new innovative methodologies are greatly needed.

\section{ACKNOWLEDGMENTS}

This work was mainly funded by Prof. Willy Schmid of the Swiss Federal Institute of Technology in Zurich. We would like to thank Corinne Lundström, Corina Lardelli, Susanne Kytzia, and Mattia Wegmann for providing data used in the case study. They were funded by the ALPSCAPE project under Swiss NRP48 (No 4048-064441). Thanks are also due to Irmi Seidl, 2 anonymous reviewers, and the Guest Editor of this issue, who all provided numerous helpful comments on an earlier version of the manuscript.

\section{AUTHORS}

Adrienne Grêt-Regamey

Swiss Federal Institute of Technology in Zurich, Institute for Spatial and Landscape Planning, ETH Hönggerberg, 8093 Zurich, Switzerland. gret@nsl.ethz.ch

Ariane Walz and Peter Bebi

Swiss Federal Institute for Snow and Avalanche Research (WSL), Ecosys tem Boundaries Research Unit, 7260 Davos, Switzerland walz@slf.ch (A.W.); bebi@sIf.ch (P.B.)

\section{REFERENCES}

ADB [Asian Development Bank]. 1990. Environmental Risk AssessmentDealing with Uncertainty in Environmental Impact Assessment. Manila, Philippines: Asian Development Bank.

Aspinall R. 1992. An inductive modeling procedure based on Bayes' theorem for analysis. Geographical Information Systems 6:105-121.

Atkinson SE, Crocker TD, Shogren JF. 1992. Bayesian exchangeability, benefit transfer, and research efficiency. Water Resources Research

28:715-722.

Baumgart K. 2005. Bewertung landschaftsrelevanter Projekte im Schweizer Alpenraum. Die Methode der Discrete-Choice-Experimente. Berne, Switzerland: Geographica Bernensia.

Bebi P, Kytzia S, Lundstrom C, Walz A, Grêt-Regamey A, Lardelli C. 2005. Am Beispiel der Landschaft Davos-Simulation und Bewertung von Zukunftsszenarien Alpiner Regionen [in German]. Schlussbericht NFP-48.

Berne, Switzerland: Swiss National Science Foundation.

Bergland 0. 2006. Benefit Transfer: A Hierarchical Bayesian Approach. Asia-Pacific School of Economics and Government Working Paper. Canberra, Australia: The Australian National University.

Bicknell KB, Ball RJ, Cullen R, Bigsby HR. 1998. New methodology for the ecological footprint with an application to the New Zealand economy. Ecological Economics 27:149-160.

Bockstael NE, Costanza R, Strand IE, Boynton W, Bell K, Wainger LA.

1995. Ecological economic modeling and valuation of ecosystems. Ecologi cal Economics 14:143-159.

Bollmann K, Graf RF, Debrunner R, Suter W. 2004. The capercaillie as an indicator of high species richness: Potential and limitations of the umbrella species concept. In: Smithers R, editor. Landscape Ecology of Trees and Forests. Proceedings of the twelfth annual IALE(UK) conference, held at Royal Agricultural College, Cirencester, 21-24 June 2004. Cirencester, United Kingdom: International Association for Landscape Ecology (UK Region), pp 200-207.

Boyd J, Banzhaf HS. 2007. What are ecosystem services? The need for standardized environmental accounting units. Ecological Economics 63:616-626.

Chan KMA, Shaw MR, Cameron DR, Underwood EC, Daily GC. 2006. Conservation planning for ecosystem services, PLoS Biology 4:2138-2151.

Costanza R, d'Arge R, de Groot RS, Farber S, Grasso M, Hannon B, Limburg

K, Naeem S, O'Neill RV, Paruelo J, Raskin RG, Sutton P, van den Belt M.
1997. The value of the world's ecosystem services and natural capital. Nature 387:253-260.

Daily GC. 1997. Nature's Services: Societal Dependence on Natural Ecosystems. Washington, DC: Island Press.

Eade DOE, Moran D. 1996. Spatial economic valuation: Benefits transfer using Geographical Information Systems. Journal of Environmental Manage ment 48:97-110.

Elsasser P, Meyerhoff J. 2007. A Bibliography and Data Base on Environmental Benefit Valuation Studies in Austria, Germany and Switzerland. Part I: Forestry Studies. Hamburg, Germany: Federal Research Centre for Forestry and Forest Products. Available at

http://www.bfafh.de/bibl/pdf/iii_07_01.pdf; accessed on 4 April 2008.

Faber MH, Rackwitz R. 2004. Sustainable decision making in civil engineering. Structural Engineering International 14:237-242.

FOEN [Swiss Federal Office for the Environment]. 2006. Swiss Greenhouse Gas Inventory. http://www.bafu.admin.ch/climatereport-

ing/00545/04333/index.html?lang=en; accessed on 4 April 2008.

Getzner M. 2000. Hypothetical and real economic commitments, and social status in valuing a species protection program. Journal of Environmental Planning and Management 43(3):541-559.

Gios G, Goio I, Notaro S, Raffaelli R. 2006. The value of natural resources for tourism: A case study of the Italian Alps. International Journal of Tourism Research 8(2):77-85.

Glück $\boldsymbol{P}$, Kuen H. 1977. Der Erholungswert des Grossen Ahornbodens [in German]. Allgemeine Forstzeitung 88:7-11.

Goio I, Gios G, Pollini C, Notaro S. 2005. The development of forest accounting in the province of Trento. The International Forestry Review 7(5):298-316.

Graf RF, Bollmann K, Suter W, Bugmann H. 2005. The importance of spatial scale: Capercaillie in the Swiss Alps. Landscape Ecology 20(6):703-717.

Grêt-Regamey A, Bebi P, Bishop ID, Schmid W. 2007a. Linking GIS-based models to value ecosystem services in an Alpine region. Journal of Environmental Management, Article in Press, Corrected Proof, 7 September 2007. doi:10.1016/j.jenvman.2007.05.019

Grêt-Regamey A, Bishop ID, Bebi P. 2007b. Predicting the scenic beauty value of mapped landscape changes in a mountainous region through the use of GIS. Environment and Planning B: Planning and Design 34(1):50-67. 
Grêt-Regamey A, Kytzia S. 2007. Integrating the valuation of ecosystem services into input output economics of an Alpine region. Ecological Economics 63:786-798.

Grêt-Regamey A, Straub D. 2006. Spatially explicit avalanche risk assessment linking Bayesian networks to a GIS. Natural Hazards and Earth System Sciences 6:911-926.

Gruber U. 1999. Der Einsatz numerischer Simulationsmethoden in der Lawinengefahrenkartierung [PhD dissertation, in German]. Zurich, Switzerland: University of Zurich.

Hackl F, Pruckner GJ. 1997. Contingent Valuation als Instrument zur ökonomischen Bewertung der Landschaft [in German]. Frankfurt am Main, Germany: Lang.

Hackl S. 2007. Eine ökonomische Bewertung von Artenschutzprogrammen-Der Luchs im Nationalpark O.ö. Kalkalpen [in German]. Report 162007. Graz, Austria: Wegener Center for Climate and Global Change, University of Graz.

Hasselmann K, Hasselmann S, Giering R, Ocana V, von Storch H. 1997. Sensitivity Study of Optimal $\mathrm{CO}_{2}$ Emission Paths Using a Simplified Struc tural Integrated Assessment Model (SIAM). Climate Change 37:345-386. Heal G. 2000. Nature and the Marketplace. Capturing the Value of Ecosystem Services. Washington, DC: Island Press.

Heal G, Kriström B. 1998. National Income and the Environment. Umeå, Sweden: Department of Forest Economics.

Higgins SI, Turpie JK, Costanza R, Cowling RM, Le Maitre DC. 1997. An ecological economic simulation model of mountain fynbos ecosystems: Dynamics, valuation and management. Ecological Economics 22:155-169. Jäggin B. 1999. Der monetäre Wert der Artenvielfalt im Jura [PhD dissertation, in German]. Zurich, Switzerland: University of Zurich.

Kytzia S, Walz A, Wegmann M. In press. How can the tourism sector make more efficient use of land? A model-based approach to eco-efficiency for tourist destinations. Available from Ariane Walz.

Lehr U. 2005. Bayesian benefit transfer in environmental valuation. Paper presented at the International Conference on Policy Modeling (EcoMod2005), Istanbul, 29 June - 2 July 2005. Available at http://www. ecomod.net/conferences/ecomod2005/ecomod2005_papers.htm; accessed on 4 April 2008.

León CJ, Vásquez-Polo FJ, Gonzales RL. 2002. Elicitation of expert opinion in benefit of transfer of environmental goods. Environmental and Resource Economics 26(2):199-210.

Löwenstein W. 1995. Die monetäre Bewertung der Schutzfunktion des Waldes vor Lawinen und Rutschungen in Hinterstein (Allgäu) [in German]. In: Bergen V, Löwenstein W, Pfister G. Studien zur monetären Bewertung von externen Effekten der Forst- und Holzwirtschaft. Schriften zur

Forstökonomie 2. 2nd edition. Frankfurt am Main, Germany: Sauerländer, pp 117-178.

Lundström C, Kytzia S, Walz A, Grêt-Regamey A, Bebi P. 2007. Linking models of land use, resources, and economy to simulate the development of mountain regions (ALPSCAPE). Environmental Management 40:379-393. Mallawaarachchi T, Walker PS, Young MD, Smyth RE, Lynch HS, Dudgeon G. 1996. GIS-based integrated modeling systems for natural resource management. Agricultural Systems 50:169-189.

Matthews HS, Small M. 2001. Extending the boundary of life-cycle assessment through environmental economic input-output models. Industrial Ecology 4:7-10.

Merz HA, Schneider T, Bohnenblust H. 1995. Bewertung von technischen Risiken-Beiträge zur Strukturierung und zum Stand der Kenntnisse. Modelle zur Bewertung von Todesfallrisiken [in German]. Zurich, Switzerland: vdf Hochschulverlag.

Meyerhoff J, Elsasser P. 2007. A bibliography on stated preference studies in Austria, Germany and Switzerland. In: Meyerhoff J, Lienhoop N, Elsasser P, editors. Stated Preference Methods for Environmental Valuation: Applications from Austria and Germany. Marburg, Germany: Metropolis Verlag. Naidoo R, Ricketts TH. 2006. Mapping the economic costs and benefits of conservation. PLoS Biology 4:2153-2164.

Nathwani JS, Lind NC, Pandey MD. 1997. Affordable Safety by Choice: The Life Quality Index Method. Report. Waterloo, Canada: Institute for Risk Research, University of Waterloo.

Nordhaus WD. 1994. Managing the Global Commons: The Economics of Climate Change. Cambridge, MA: The MIT Press.

Office for National Statistics. 2008. Harmonised Index of Consumer Prices (HICP). National Statistics. http://www.statistics.gov.uk/StatBase/

tsdataset.asp?vlnk=340\&More=Y; accessed on 4 April 2008.
Parfit D. 1993. Energy policy and the further future: The social discount rate. In: MacLean D, Brown PG, editors. Energy and the Future. Landham, MD: Rowman and Littlefield

Rackwitz $\boldsymbol{R}$. 2000. Optimization-the basis for code-making and reliability verification. Structural Safety 22:27-60.

Schmidtke $\boldsymbol{H}$, Kägi W. 2006. Möglichkeiten zur Anrechnung von "Forest Management" in der Schweiz als Senken gemäss Kyoto-Protokoll Art. 3.4 [in German]. Report prepared for the Swiss Federal Office for the Environment by Silvaconsult AG, Winterthur, and B,S,S. Volkswirtschaftliche Beratung AG, Basel. Available at

http://www.bafu.admin.ch/wald/01198/01209/index.html?lang=de; accessed on 4 April 2008.

SFSO [Swiss Federal Statistical Office]. 2001. Land Use Statistics of Switzerland: The Changing Face of Land Use. Neuchâtel, Switzerland: SFSO. Stassopoulou A, Petrou M, Kittler J. 1998. Application of a Bayesian network in a GIS based decision-making system. International Journal of Geographical Information Systems Science 12:23-45.

Suh S, Huppes G. 2002. Missing inventory estimation tool using extended input-output analysis. International Journal for Life Cycle Assessment 7:134-140.

Suh S, Lenzen M, Treloar G, Hondo H, Horvath A, Huppes G, Jolliet O, Klann U, Krewitt W, Moriguchi Y, Munksgaard J, Norris G. 2004. System boundary selection for life cycle inventories. Environmental Science and Technology 38:657-664.

Suter W, Graf RF, Hess R. 2002. Capercaillie (Tetrao urogallus) and avian biodiversity: Testing the umbrella species concept. Conservation Biology 16(3):778-788.

Sutton PC, Costanza R. 2002. Global estimates of market and non-market values derived from nighttime satellite imagery, land cover, and ecosystem service valuation. Ecological Economics 41:509-527.

Tangerini A, Soguel N. 2004. Evaluation monétaire de la qualité du paysage. IDHEAP Working Paper 6/2004. Chavannes-près-Renens, Switzerland: Swiss Graduate School of Public Administration (IDHEAP).

Termansen M, McClean CJ, Scarpa R. 2004. Economic valuation of Danish forest recreation combining mixed logit and GIS. Paper presented the Association of Environmental and Resource Economists Conference in Budapest, Hungary, 25-28 June 2004. Available at

http://eaere2004.bkae.hu/eaere.php?id=1; accessed on 4 April 2008. Troy A, Wilson MA. 2006. Mapping ecosystem services: Practical challenges and opportunities in linking GIS and value transfer. Ecological Economics 60(2):435-449.

Vincent JR. 2000. Green Accounting: From Theory to Practice. Environment and Development Economics 5:13-24.

Wagner P. 2004. Chronik von 75 Jahren Golf Club Davos. Die Clubgeschichte. Golf Club Davos. http://www.golfdavos.ch/mm/ chronik_inhalt.pdf; accessed on 4 April 2008.

Walz A. 2006. Land Use Modelling for an Integrated Approach to Regional Development in the Swiss Alps [PhD dissertation]. Zurich, Switzerland: University of Zurich.

Walz A, Lardelli C, Behrendt M, Grêt-Regamey A, Lundstrom C, Kytzia S,

Bebi P. 2007. Participatory scenario analysis for integrated regional modeling. Landscape and Urban Planning 81:114-131.

WCED [World Commission on Environment and Development]. 1987. Our Common Future: Report of the World Commission on Environment and Development. Oxford, United Kingdom: Oxford University Press.

Westman WE. 1977. How much are nature's services worth? Science 197:960-963.

Wiedmann T, Minx J, Barrett J, Wackernagel M. 2006. Allocating ecologica footprints to final consumption categories with input-output analysis. Ecological Economics 56:26-48.

Williams EV, Rirn JR, Kind V, Robers M, McGlashan D. 2003. The value of Scotland's ecosystem services and natural capital. European Environment 13:67-78.

Wilson MA, Hoehn JP. 2006. Valuing environmental goods and services using benefit transfer: The state-of-the-art and science. Ecological Economics 60:335-348.

Wilson MA, Howarth RB. 2002. Discourse-based valuation of ecosystem services: Establishing fair outcomes through group deliberation. Ecological Economics 41:431-443. 